\title{
Meraih Hidup Bermakna: Logoterapi untuk Menurunkan Depresi pada Perempuan Korban KDRT
}

\author{
Qurrota A'yuni Fitriana ${ }^{1} \mathcal{E}$ M. Noor Rochman Hadjam ${ }^{2}$ \\ ${ }^{1,2}$ Fakultas Psikologi Universitas Gadjah Mada
}

\begin{abstract}
Women victims of domestic violence experience both physical and psychological trauma that may contribute in the emergence of depression symptoms. Depression is a condition when individu losing their meaning of life. The intervention for making meaningful life discovered by Viktor Frankl that named logotherapy. The purpose of this study is to investigate the effectiveness of logotherapy in reducing depression for women victims of domestic violence. One-group pretest-posttest design by using a double pretest was applied. Beck Depression Inventory II (BDI-II) and meaning in life scale as manipulation check was used. The participants of this study are 6 womens. Logotherapy was administered for 6 sessions in 3 weeks. The result of this study are similar with the hypothesis showed where logotherapy significantly decreased depression in women victims of domestic violence $\left(F_{(r)}=9.333, p=.000\right)$. This study used logotherapy group, whereas among participants have a chance to share their feelings and mutual enforcing for meaningful life.
\end{abstract}

Keywords: depression, domestic violence, logotherapy

\begin{abstract}
Abstrak. Perempuan korban KDRT dari pasangannya mengalami berbagai trauma baik fisik maupun psikis yang dapat berakibat pada munculnya simtom-simtom depresi. Tujuan dari penelitian ini ialah mengetahui efektivitas logoterapi dalam menurunkan depresi pada perempuan korban KDRT. Desain penelitian yang digunakan ialah one-group pretest-posttest design using a double pretest. Instrumen penelitian terdiri dari Beck Depression Inventory II (BDI-II) dan skala kebermaknaan hidup sebagai cek manipulasi. Intervensi logoterapi dilaksanakan selama 6 pertemuan dalam 3 minggu. Logoterapi yang dalam studi ini berbentuk kelompok dengan jumlah partisipan 6 orang perempuan. Hasil penelitian sesuai dengan hipotesis penelitian bahwa logoterapi terbukti secara signifikan dapat menurunkan depresi pada perempuan korban $\operatorname{KDRT}\left(F_{(r)}=9.333, p=.000\right)$.
\end{abstract}

Katakunci: depresi, kekerasan dalam rumah tangga, logoterapi

Kekerasan terhadap perempuan menjadi isu penting di dunia saat ini. The World Health Organization (WHO; 2005) memberikan pernyataan bahwa perempuan memiliki risiko lebih tinggi mengalami kekerasan terhadap pasangan dibandingkan laki-laki. Salah satu tujuan dari

\footnotetext{
${ }^{1}$ Korespondensi mengenai isi artikel ini dapat dilakukan melalui: qayunif@gmail.com,

2 Atau melalui nrochman@ugm.ac.id
}

Sustainable Development Goals (SDG's) ialah pada bidang kesetaraan gender, pendidikan perempuan, dan pemberdayaan perempuan.

Angka kejadian kekerasan dalam rumah tangga (KDRT) di Indonesia menurut Lembar Catatan Tahunan Komnas Perempuan tahun 2015 sebanyak 11.207 kasus. Jumlah kasus ini meningkat sebesar $9 \%$ dari tahun 2014. Sejumlah 60\% dari kasus tersebut atau sebanyak 6725 kasus 
merupakan kasus kekerasan terhadap istri. Kekerasan fisik mendominasi dengan persentase $38 \%$ atau 4.304 kasus dibandingkan kekerasan seksual, psikis, dan ekonomi (Komnas Perempuan, 2016). Angka kejadian KDRT di Yogyakarta saat ini masih tergolong tinggi. Menurut Badan Pemberdayaan Perempuan dan Masyarakat (BPPM) DIY, kasus KDRT yang dilaporkan pada tahun 2014 sebanyak 850 kasus. Pada tahun 2015, tercatat oleh Pusat Pelayanan Terpadu Perlindungan Angka ini adalah jumlah kasus yang dilaporkan, sedangkan yang tidak dilaporkan kemungkinan lebih tinggi seperti halnya fenomena gunung es.

Dampak dari kekerasan terhadap perempuan dapat berupa luka fisik yang mengakibatkan rasa sakit berkepanjangan, maupun dampak psikologis. Dampak psikologis yang timbul berupa reaksi emosional seperti rasa takut pada banyak hal, gangguan emosional berupa kecemasan, ketegangan, rasa sedih, hingga simtom depresi (Williamson, 2004). Penelitian dari Filson, Ulloa, Runfola, dan Hokoda (2010) menyimpulkan bahwa kekerasan yang dilakukan oleh pasangan dapat memengaruhi depresi pada perempuan karena adanya rasa ketidakberdayaan yang diciptakan dari konflik tersebut.

Seligman dan Walker (Lianawati, 2009) menggambarkan bahwa perempuan yang mengalami kekerasan secara terus menerus akan menampilkan rasa tidak berdaya yang dipelajari (learned helplessness). Semakin lama korban KDRT akan belajar bahwa upaya apapun yang ia lakukan tidak akan membuatnya bebas dari relasi kekerasan tersebut. Ia menjadi pasif karena merasa tidak yakin lagi bahwa responnya akan menghasilkan apa yang ia inginkan. Lebih lanjut, kekerasan yang dialami perempuan khususnya yang dilakukan oleh orang ter-dekatnya dapat memicu munculnya depresi.
Depresi merupakan sebuah kondisi yang melibatkan fisik dan psikis individu terganggu keberfungsiannya. Depresi dapat muncul karena adanya interaksi antara lingkungan dan genetis, dengan stressor dari lingkungan yang menjadi faktor utama pencetusnya (Thase, 2014). Secara neurobiologis, depresi merupakan adanya abnormalitas pada otak yang merupakan pusat pengaturan perilaku. Depresi disebabkan karena adanya perubahan volume pada bagian otak prefrontal cortex, amygdala, dan hippocampus (Palazidou, 2012). Villanueva (2013) menyebutkan bahwa depresi dimulai karena adanya disfungsi pada Hypothalamic-Pituitary Adrenal axis (HPA axis) dan perubahan hormon. Sistem monoaminergic yang bersamaan dengan HPA axis memengaruhi jalannya serotonin, norepinephrine, dan dopamine. Sistem serotonin berkaitan dalam pengaturan emosi yang berfungsi untuk mengontrol perhatian terhadap hal negatif (De Raedt \& Koster, 2010). Selain itu dalam ringkasan yang diajukan oleh Morgan (2015), depresi menjadi lebih persisten pada individu dikarenakan adalanya pola berpikir negatif yang membuat individu menjadi reaktif terhadap stres dan memicu suasana hati negatif.

Penanganan terhadap depresi pada umumnya adalah dengan pengobatan farmakologi dan intervensi psikologi. Hasil penelitian dari Goodwin (2015) memberikan saran bahwa pengobatan psikotropika dengan vortioxetine berdasarkan hasil brain imaging untuk depresi dapat menjadi solusi. Beberapa intervensi psikologi yang digunakan untuk mengatasi depresi yaitu dengan pendekatan kognitif yang berfokus pada penyadaran atau pengubahan pola pikir yang disfungsional untuk menurunkan simtom-simtom depresi (Beck \& Alford, 2009). Intervensi lain yaitu dengan pendekatan keperilakuan yang berfokus pada perilaku depresi merupakan perilaku yang dapat dipelajari dan 
dapat dihilangkan. Terapi keperilakuan bertujuan untuk memodifikasi perilaku individu (Nevid, Rathus, \& Greene, 2005).

Salah satu penanganan psikologis yang digunakan dalam mengatasi masalah depresi ialah dengan pendekatan humanistik. Khususnya logoterapi, memiliki tiga asumsi dasar yang saling berkaitan satu sama lain yaitu the freedom of will (kebebasan berkehendak), the will to meaning (hasrat untuk hidup bermakna), dan the meaning of life (makna hidup) (Baihaqi, 2008; Bastaman, 2007; Frankl, 1967; 2004, Schultz, 1991; Semiun, 2006; Tomy, 2014).

Menurut pendekatan logoterapi, sumber-sumber makna hidup terdiri dari tiga nilai (values) yaitu antara lain creative values, experiential values dan attitudinal values (Baihaqi, 2008; Bastaman, 2007; Frankl, 1967; Schultz, 1991; Semiun, 2006). Selain itu, sumber makna hidup juga berasal dari adanya pengharapan berupa keyakinan akan terjadinya perubahan yang lebih baik di masa mendatang dan sikap optimis menyongsong masa depan. Orang yang berpengharapan akan menemukan makna dalam hidupnya, sekalipun ia dalam penderitaan (Bastaman, 2007). Hal terakhir ialah ibadah yaitu upaya men-dekatkan diri kepada Tuhan dengan cara-cara yang diajarkan oleh-Nya, yaitu agama. Ibadah akan memberikan perasaan tente-ram, mantap, dan tabah serta meng-harapkan petunjuk dalam melakukan suatu perbuatan.

Logoterapi tidak hanya dapat diterapkan pada seting individu, namun juga pada seting pasangan dan kelompok. Lantz (1998) melaksanakan penelitian kelompok terapi interaksional Viktor Frankl dan menemukan bahwa bentuk kelompok dapat memfasilitasi individu untuk berubah. Sebagai contoh, penelitian dari Winters dan Hutzell (2010) membuktikan bahwa logoterapi terbukti efektif memfasilitasi penerimaan dan per- tumbuhan transendensi diri pada intervensi yang dilakukan berpasangan. Dukungan dalam kelompok menjadi aspek penting bagi perempuan untuk bisa mengekspresikan pikiran dan perasaannya.

Hipotesis yang dapat diajukan dalam penelitian ini ialah bahwa logoterapi dapat menurunkan depresi pada perempuan korban KDRT.

\section{Metode}

Variabel perlakuan (independent variable) dalam penelitian ini yaitu logoterapi. Sedangkan variabel tergantung (dependent variable) yaitu simtom depresi. Partisipan yang terlibat dari awal hingga akhir berjumlah 6 orang dengan kriteria: (a) mengalami kekerasan dalam rumah tangga dalam bentuk fisik, psikis, dan atau ekonomi, (b) memiliki skor skala depresi ringan hingga berat, (c) tidak sedang menjalani intervensi psikologi (d) tidak tinggal dengan suami/sudah berpisah dengan suami, (e) dapat berkomunikasi dan mampu membaca dan menulis dengan tujuan dapat menyampaikan perasaan serta pikirannya selama pelaksanaan intervensi, dan (f) bersedia berpartisipasi sebagai partisipan penelitian yang dibuktikan dengan mengisi informed consent penelitian.

Instrumen yang digunakan untuk mengukur depresi ialah Beck Depression Inventory II (BDI - II) yang telah diadaptasi dan divalidasi di Indonesia oleh Ginting, Naring, Veld, Srisayekti, dan Becker (2013). Instrumen tersebut terdiri dari 21 aitem.

Penelitian ini mengunakan eksperimen kuasi dengan desain penelitian "Onegroup pretest-posttest design using a double pretest". Peneliti hanya melibatkan kelompok eksperimen yaitu kelompok yang menerima intervensi logoterapi karena keterbatasan partisipan yang ber-sedia untuk mengikuti terapi. 
$\begin{array}{lllll}\mathrm{NR} & \mathrm{O}_{1} & \mathrm{O}_{2} & \mathrm{X} & \mathrm{O}_{3}\end{array}$

\section{Keterangan:}

NR = Kelompok Non-Random

$\mathrm{O}_{1}=$ Pretest 1

$\mathrm{O}_{2} \quad=$ Pretest 2

$\mathrm{X}=$ Intervensi Logoterapi

$\mathrm{O}_{3}=$ Posttest

Data penelitian dianalisis dengan analisis kuantitatif untuk menguji hipotesis menggunakan uji Friedman. Uji Friedman dilakukan untuk mengetahui apakah terdapat perbedaan antara pretest 1 , pretest 2 , dengan posttest secara bersamaan. Uji kedua yang dilakukan ialah uji Wilcoxon Signed Ranked Test untuk membandingkan dua kelompok mean partisipan yang sama dalam melihat perbedaannya. Analisis
Berdasarkan hasil tabel 1, dilakukan uji Wilcoxon Signed Ranked Test yang menunjukkan bahwa terdapat perbedaan

Tabel 1.

Skor Pretest dan Posttest Skala Kebermaknaan Hidup

\begin{tabular}{clcc}
\hline No & Nama & Skor pretest & $\begin{array}{l}\text { Skor } \\
\text { posttest }\end{array}$ \\
\hline 1 & Aster & 241 & 273 \\
2 & Jasmine & 237 & 289 \\
3 & Lily & 163 & 307 \\
4 & Tulip & 237 & 285 \\
5 & Rose & 191 & 222 \\
6 & Orchid & 258 & 297 \\
& Rerata & 221,16 & 278,83 \\
& SD & 36,17 & 30,09 \\
\hline
\end{tabular}

signifikan antara skor pretest dan posttest pada skala kebermaknaan hidup dengan $z=$ $-2,201, p=0,028(p<0,05)$. Terjadi pening-

Tabel 2.

Hasil Skor BDI

\begin{tabular}{clcccccc}
\hline No & Nama & Pretest 1 & Kategori & Pretest 2 & Kategori & Posttest & Kategori \\
\hline 1 & Aster & 16 & Ringan & 19 & Ringan & 5 & Normal \\
2 & Jasmine & 28 & Sedang & 21 & Sedang & 14 & Ringan \\
3 & Lily & 45 & Berat & 31 & Berat & 5 & Normal \\
4 & Tulip & 15 & Ringan & 19 & Sedang & 2 & Normal \\
5 & Rose & 27 & Sedang & 26 & Sedang & 19 & Ringan \\
6 & Orchid & 15 & Ringan & 14 & Ringan & 2 & Normal \\
& Mean & 24,33 & & 21,67 & & 7,83 &
\end{tabular}

tambahan dilengkapi dengan analisis kualitatif berupa hasil observasi selama jalannya proses intervensi, wawancara dengan partisipan, serta hasil dari lembar kerja partisipan selama pelaksanaan intervensi.

\section{Hasil}

Partisipan yang terlibat dalam pene-litian ini berjumlah 6 orang, berusia antara 30 hingga 45 tahun. Pendidikan minimal yaitu SMA/SMK dan pendidikan tertinggi yaitu S1. Seluruh partisipan beretnis Jawa. Tiga orang di antaranya berstatus cerai, sedangkan tiga partisipan lainnya statusnya berpisah. Dalam pembahasan ini peneliti mengganti nama partisipan menjadi nama samaran untuk menjaga kerahasiaan partisipan. katan rerata sebesar 57,67 poin dimana hasil posttest $(M=278,83$ dan $S D=30,09)$ lebih tinggi dibandingkan hasil pretest $(M=$ $221,16$ dan $S D=30,09)$. Hal ini menunjukkan bahwa terdapat perubahan yang signifikan kebermaknaan hidup berdasarkan hasil pretest dan posttest pada partisipan yang diukur melalui skala kebermaknaan hidup.

Berdasarkan hasil uji Friedman dihasilkan nilai $F_{(r)}=9,333, p=0.000 \quad(p<$ $0,05)$. Hal ini menunjukkan bahwa ter-dapat perbedaan yang signifikan depresi pada pretest 1 , pretest 2 , dan posttest. Selanjutnya dilakukan prosedur post-hoc dengan cara uji Wilcoxon Signed Ranked Test untuk menganalisis perbedaan skor BDI masingmasing pada pretest 1 dengan pretest 2, pretest 2 dengan posttest, dan pretest 1 
dengan posttest. Nilai signifikansi yang dilakukan dengan mengikuti bonferroni procedures (Field, 2009). Cara yang biasa digunakan dalam ilmu sosial untuk menerima nilai signifikansi bukan dengan nilai 0,05, melainkan dengan mem-bagi nilai signifikansi 0,05 dengan perbandingan yang dilakukan yaitu 3 kali. Nilai tersebut ialah $\frac{0,05}{3}=0,167$. Pada pengukuran pretest 1 dengan pretest 2 , menghasilkan nilai $z=-0,736$ dan $p=0,231$ $(p>0,167)$. Hal ini menunjukkan bahwa tidak ada perbedaan yang signifikan antara kondisi pretest 1 dengan pretest 2 . Pada pengukuran pretest 2 dengan posttest menghasilkan nilai $z=-2,207$ dan $p=0,0135(p<$ $0,167)$. Artinya terdapat perbedaan yang signifikan antara pretest 2 dengan post test. Sedangkan untuk pengukuran pretest 1 dengan posttest mendapatkan hasil nilai $z=$ $-2,207$ dan $p=0,0135(p<0,167)$, yang berarti terdapat perbedaan yang signifikan antara pretest 1 dengan posttest.

Berikutnya, dilakukan analisis effect size untuk mengetahui sumbangan efektif logoterapi terhadap penurunan depresi pada perempuan korban KDRT. Pengukuran effect size dilakukan dengan rumus $r=$ $\frac{\Xi}{\sqrt{N}}$. Effect size ini dihitung dari hasil pretest 2 dengan posttest, yaitu $r=\frac{-2,207}{\sqrt{12}}=-0,63$. Menurut Cohen (Field, 2009), nilai di atas 0,5 dapat diartikan memberikan efek yang besar. Hasil tersebut menunjukkan bahwa logoterapi memberikan efek yang besar terhadap penurunan depresi pada perempuan korban KDRT.

\section{Diskusi}

Penelitian ini bertujuan untuk menguji efektivitas logoterapi untuk menurunkan depresi pada perempuan korban KDRT. Intervensi logoterapi yang diberikan selama 6 kali pertemuan selama 3 minggu terbukti mampu menurunkan tingkat depresi pada perempuan korban KDRT. Begitu juga dengan tingkat kebermaknaan hidup yang juga meningkat sesudah di-berikan intervensi logoterapi. Hal ini sesuai dengan studi sebelumnya dari Cho, Bernstein, Roh, dan Chen, (2013) bahwa logoterapi dapat menurunkan depresi serta untuk menemukan kembali makna hidup pada perempuan imigran Korea. Sejalan dengan hasil tersebut, hasil studi sebe-lumnya dari Cho (2008) menunjukkan bahwa logoterapi efektif dalam menurunkan depresi pada perempuan yang memiliki suami alkoholik.

Kekerasan yang dilakukan oleh suami kepada istrinya dapat menjadi salah satu penyebab depresi pada seorang perempuan. Salah satu penyebab depresi ialah adanya frustrasi eksistensial (Bastaman, 2007). Individu merasa tidak memiliki makna dalam hidupnya (meaningless), tidak memiliki harapan (hopelessness), dan merasa tidak berdaya (helplessness). Menurut penelitian dari Filson, et al. (2010) bahwa ada faktor lain yang memoderasi antara kekerasan dengan depresi, yaitu adanya rasa tidak berdaya pada perempuan (helplessness). Laki-laki membuktikan kekuatan (power) pada pasangannya melalui perbuatan menyakiti secara fisik, psikis, ekonomi maupun seksual yang dapat dikategorikan sebagai kekerasan. Hal ini membuat perempuan menjadi tidak berdaya dan menjadikan dirinya terpuruk sehingga muncul simtom-simtom depresi. Semakin sering perempuan merasakan ketidakberdayaan semakin rentan dirinya menjadi depresi. Lebih lanjut, prevalensi perempuan lebih tinggi untuk mengalami depresi dibandingkan laki-laki sebanyak 2 hingga 3 kali, apalagi perempuan tersebut memiliki riwayat pernah mengalami kekerasan oleh pasangannya sendiri maka kemungkinan depresinya bertambah menjadi 1,5 hingga 2 kali lipat (Beydoun, Beydoun, Kaufman, Lo, \& Zonderman, 2012).

Hasil terapi ini menunjukkan bahwa proses logoterapi selama enam sesi perlahan dapat memberikan dampak bagi 
aspek-aspek depresi yaitu kognitif, afektif, dan somatis yang dialami partisipan. Melalui proses pemahaman diri, partisipan mengenali kekuatan dan kelemahan dalam dirinya. Hal ini dapat mengubah pandangan negatif yang selama ini diyakini oleh individu terhadap dirinya. Individu yang mengalami depresi lebih memfokuskan diri pada penilaian diri negatif (Beck \& Alford, 2009). Penilaian negatif individu dialihkan agar individu bisa ke arah yang lebih positif dengan cara mengenali sifat-sifat yang ingin ditingkatkan dan ingin dikurangi. Hal ini tentu disesuaikan dengan kemampuan dan kondisinya saat ini.

Pada sesi bertindak positif dan pengakraban hubungan, partisipan diajak untuk melakukan tindakan positif dan mengenali hubungan baiknya dengan orang lain. Seluruh partisipan memilih ibu sebagai orang yang memiliki hubungan bermakna dengannya. Hal ini dikarenakan ibu ialah seseorang yang tulus menyayangi dan mencintainya. Menurut Frankl (2004), cinta dapat membuat individu bisa lebih menyadari esensi manusia lain sepenuhnya dan bisa membantu orang yang dicintai mewujudkan cita-citanya. Ketika individu menyadari bahwa dirinya memiliki hubungan yang baik dengan orang lain serta bisa melakukan hal positif terhadap orang lain, hal ini membantu individu dalam berkontemplasi dan mengidentifikasi bahwa dirinya dapat melakukan sesuatu yang berguna bagi orang lain.

Salah satu sumber makna hidup ialah dari perwujudan nilai-nilai kreatif. Perwujudan nilai kreatif yang dilakukan oleh partisipan terdiri dari berbagai macam kegiatan. Jasmine, Lily, dan Tulip memilih fokus untuk membesarkan anak yang masih berusia kecil. Sedangkan Aster, Rose, dan Orchid bergabung dan aktif dalam padepokan perempuan yang bergerak di bidang kesetaraan perempuan untuk memberikan suara dalam kesetaraan gender. Kok, Goh, dan Gan (2015) dalam hasil penelitiannya menyebutkan bahwa memberikan kontribusi bagi masyarakat dan bagi orang lain merupakan salah satu sumber makna hidup terbesar. Hal ini akan menimbulkan kegembiraan pada diri seseorang, sehingga dapat menurunkan level kesedihan yang dialami individu karena ia dapat melakukan hal yang bermanfaat.

Pada pendalaman nilai-nilai penghayatan, partisipan memillih kata mutiara yang menjadi pedoman dalam hidupnya. Kata-kata tersebut menjadi semangat tersendiri bagi individu dalam melangkah. Partisipan juga dapat lebih menghayati cinta yang diberikan oleh anak kepada dirinya, beberapa di antaranya merasa bahwa menghayati cinta dapat membuat hati menjadi tenteram dan nyaman. Perasaan nyaman tersebut berkontribusi dalam perubahan aspek afektif yang dialami oleh partisipan.

Pada pendalaman nilai bersikap, beberapa partisipan memutuskan untuk bercerai setelah mengalami KDRT. Mereka melawan dengan menuntut cerai dan memilih berjuang menghidupi diri sendiri dan anak tanpa bantuan dari pasangannya lagi. Sedangkan beberapa di antara partisipan memilih tetap bertahan hingga saat ini. Fase dimana individu memilih untuk mempertahankan rumah tangganya tersebut, diwarnai dengan perasaan negatif dan tertekan. Individu dihadapkan pada kenyataan bahwa pasangan yang mencintainya ternyata memperlakukannya tidak baik. Hal ini membuat individu mengalami fase penderitaan dan terjebak dalam siklus kekerasan. Siklus kekerasan yang dialami merupakan pengulangan pola dari melakukan kekerasan (violence episode, honeymoon period, violence escalation) kemudian diikuti permintaan maaf, pemaafan, kebahagiaan, kemudian peningkatan kekerasan (White, Klein, \& Martin, 2015). Sikap partisipan dalam mengatasi rasa ketidakberdayaan yaitu 
dengan melakukan kegiatan bermanfaat bagi dirinya dan orang lain. Kegiatan tersebut dapat membuatnya menjadi lebih kuat dan bermakna. Partisipan Jasmine, Lily, dan Tulip meski sudah tidak tinggal serumah, mereka masih dalam status pernikahan. Pada partisipan Tulip, ia memilih untuk segera mengurus proses bercerai. Partisipan Lily memilih fokus untuk membesarkan anaknya yang masih berusia 2 tahun. Sedangkan Jasmine dalam intervensi ini berproses dan membuatnya mengurungkan niat untuk bercerai. Jasmine berniat untuk memperbaiki hubu-ngannya dengan suami. Penyebabnya tak lepas dari pengalaman Jasmine sebelum-nya yang pernah bercerai di pernikahan pertama. Di pernikahan kedua ini, ia ber-harap untuk bisa selamanya. Hal ini mematahkan pendapat yang disampaikan oleh Berk (2012) bahwa pernikahan kedua memiliki persentase yang sama untuk mengalami perceraian dengan pernikahan pertama. Jasmine memiliki pertimbangan bahwa kebahagiaan anak adalah yang utama. Hal ini merupakan perwujudan dari prinsip dasar logoterapi yaitu freedom of will yang berarti kemampuan individu untuk memilih dan bertanggung jawab atas pilihannya (Frankl, 1967). Individu tidak lagi merasa bingung dalam meng-ambil keputusan dan menentukan sikap yang terbaik bagi dirinya.

Pada nilai pengharapan, individu dapat mengungkapkan harapan-harapan di masa yang akan datang mengenai kehidupannya. Harapan ini merupakan bagian dari pencapaian tujuan hidup. Tujuan hidup tidak dapat dipisahkan dari makna hidup. Secara disadari, partisipan berproses untuk mencari makna hidupnya, sesuai dengan prinsip will to meaning (hasrat untuk hidup bermakna) yaitu individu termotivasi untuk mencari makna dan memberikan makna pada hidupnya (Bastaman, 2007). Setiap individu memiliki keinginan untuk menjadi individu yang bermartabat dan berguna bagi dirinya, keluarga dan lingkungannya serta di mata Tuhan agar hidupnya terasa berarti dan berharga. Adanya pengharapan merupakan sebuah optimisme yang berbanding terbalik dengan aspek pesimisme di dalam simtom depresi.

Pendalaman nilai ibadah tidak dapat dipisahkan dari dimensi spiritual yaitu hubungan individu dengan Tuhan. Spiritualitas menjadi salah satu faktor penting dalam meraih hidup yang bermakna. Manusia merupakan kesatuan utuh dimensi ragawi, kejiwaan dan spiritual (bio-psikososiokultural-spiritual) mengi-ngat manusia senantiasa hidup dalam suatu lingkungan sosial budaya tertentu (keluarga, lingkungan, pendidikan, masyarakat) yang juga berpengaruh ter-hadap perkembangan kepribadian (Baihaqi, 2008; Bastaman, 2007). Cara meraih makna hidup ialah salah satunya dengan mengalami transendensi diri, di-mana individu memiliki kemampuan untuk melupakan dirinya dengan berserah diri dan mengabdi pada sebuah tujuan. Sebuah upaya perwujudan diri yang diperoleh sebagai efek samping dari upaya diri memahami makna kehidupan (Alling, 2015; Barnes, 2000; Crumbaugh, 1979; Frankl, 2004). Dalam konteks studi ini, partisipan dapat merasakan bahwa masalah yang dialaminya membuatnya menjadi lebih dekat kepada Tuhan. Sumber penolong utama yang bisa diandalkan hanyalah Tuhan, sehingga dari sanalah muncul arti bahwa mereka berharga dan bermakna. Hal ini dirasakan oleh par-tisipan Tulip yang rajin beribadah pada malam harinya. Begitu juga dengan Lily yang memiliki keyakinan bahwa dalam keadaan apapun, penolong utama yaitu dengan beribadah sholat. Hasil penelitian dari Astuti (2013) menunjukkan bahwa ada hubungan positif antara penghayatan makna sholat dan kebermaknaan hidup yang meliputi penyerahan diri, kepatuhan, dan 
ketundukan kepada Allah. Saat beribadah, sistem saraf individu menjadi lebih rileks dan detak jantung menjadi lebih lambat. Kesadaran individu ada pada fase Alfa-Teta yaitu pikiran bawah sadar yang membuatnya menjadi lebih bisa mengenal Tuhan, membangkitkan potensi jiwa dalam berinteraksi dengan Tuhan sehingga mendapatkan pengalaman batin yang mendalam. Individu menjadi lebih fokus, tensi darah menurun, dan tingkat stres menjadi rendah. Hal ini membuat wawasan berpikir menjadi luas dan terbuka sehingga individu tidak mudah terburu-buru (Mustofa, 2011).

Salah satu faktor terapeutik yang mendukung penurunan depresi ialah adanya dukungan sosial. Dukungan sosial didapatkan dengan adanya interaksi antar anggota kelompok. Diperlukan kohesivitas untuk membangun sebuah interaksi di dalam kelompok. Kohesivitas kelompok merupakan kebersamaan yang membuat fungsi dalam kelompok menjadi semakin positif (Berg, Landreth, \& Fall, 2006). Partisipan dalam kelompok dapat menjadi dirinya sendiri di dalam kelompok dan juga berperan serta dalam kelompok. Terdapat rasa kebersamaan dan kenya-manan yang dirasakan antar partisipan dalam kelompok untuk saling merasa aman. Adanya faktor dukungan yang muncul selama intervensi berlangsung, rasa penerimaan dari anggota lainnya, altruisme, universalitas, dan kohesi, dapat membuat individu untuk tetap berada dalam terapi (Brabender, Fallon, \& Smolar, 2004).

Hal lain yang mendukung terselenggaranya intervensi secara lancar adalah adanya kesamaan jenis kelamin. Faktor ini dapat meningkatkan kepuasan klien dalam proses terapeutik (Johnson \& Caldwell, 2010). Terakhir ialah interaksi yang terjalin antara partisipan dalam kelompok dengan terapis tidak dapat dilepaskan dari nilai spiritual yang dimiliki terapis (Ulrichova, 2015). Interaksi antara terapis dengan partisipan dalam logoterapi kelompok tidak dapat dilepaskan dari spiritualitas, sehingga hal ini menjadi salah satu faktor partisipan dalam mengembangkan nilai-nilai ibadahnya.

Di sisi lain, penelitian ini juga tidak terlepas dari kekurangan. Salah satunya ialah ancaman validitas statistik. Jumlah partisipan yang terbatas membuat kesimpulan statistik menjadi kurang kuat (Shadish, Cook, \& Campbell, 2002). Selain itu pengulangan pengukuran dengan alat ukur yang sama selama tiga kali, menjadi salah satu ancaman validitas internal. Alat ukur yang digunakan merupakan skala yang sama sehingga performa partisipan dapat meningkat ataupun menurun dan dimungkinkan adanya proses belajar. Studi ini juga memiliki keterbatasan dalam skrining calon partisipan di lapangan. Saat intervensi dirasa masih kurang adanya fasilitasi emosi, karena cukup banyaknya latihan-latihan yang cenderung ke ranah kognitif. Oleh karena itu, ke depannya dapat lebih banyak memfasilitasi emosi dari partisipan dalam kelompok.

\section{Kesimpulan}

Hasil penelitian menunjukkan bahwa logoterapi dalam studi ini terbukti secara signifikan menurunkan tingkat depresi pada perempuan yang mengalami KDRT. Hipotesis dalam penelitian ini terbukti. Logoterapi merupakan intervensi yang menitik beratkan pada hidup yang bermakna. Hal ini diperkuat dengan hasil cek manipulasi bahwa dengan intervensi logoterapi, kebermaknaan hidup partisipan meningkat. Tujuan utama dari logoterapi ialah menurunnya tingkat depresi pada perempuan korban KDRT dan juga menyadari kebermaknaan hidupnya, bahwa apa yang menjadi permasalahan mereka tidak menghalangi untuk bisa berkarya kembali. Tujuan ini dapat dirasakan oleh partisipan penelitian. Logoterapi 
dalam bentuk kelompok dapat memberikan manfaat bagi partisipan karena mereka dapat saling berbagi dan belajar dari pengalaman partisipan lainnya.

\section{Saran}

Bagi peneliti selanjutnya diharapkan dapat melakukan skrining yang lebih ketat mengenai durasi, frekuensi, dan jenis KDRT yang spesifik dialami oleh masing-masing partisipan untuk penentuan tingkat depresi. Selain itu bagi praktisi dapat menjadikan logoterapi bentuk kelompok sebagai salah satu pilihan psikoterapi yang dapat digunakan pada perempuan depresi pada kasus KDRT.

\section{Kepustakaan}

Alling, F. A. (2015). The healing effects of believe in medical practices and spirituality. Explore, Elsevier Inc, 11, 273-280. doi: 10.1016/j.explore.2015. 04.002 .

Astuti, D. Y. (2013). Hubungan penghayatan makna sholat dan kebermaknaan hidup pada siswa MAN Tempel Sleman Yogyakarta. (Tesis tidak dipublikasikan). Universitas Islam Negeri Sunan Kalijaga, Yogyakarta.

Baihaqi, M. I. F. (2008). Psikologi pertumbuhan: Kepribadian sehat untuk mengembangkan optimisme. Bandung: Remaja Rosdakarya.

Barnes, R. C. (2000). Viktor Frankls's logotherapy: Spirituality and meaning in the new millennium. TCA Journal Research Library, 28(1), 24-34.

Bastaman, H. D. (2007). Logoterapi: Psikologi untuk menemukan makna hidup dan meraih hidup bermakna. Jakarta: PT Raja Grafindo Persada.

Beck, A. T., \& Alford, B. A. (2009). Depression: Causes and treatment. Philadelphia: University of Pennysylvania Press.
Berk, L. E. (2012). Development Through The Lifespan (5th Edition). Boston: Pearson Education Inc.

Berg, R. C., Landreth, G. L., \& Fall, K. A. (2006). Group Counseling. New York: Routledge Taylor \& Francis Group.

Beydoun, H. A., Beydoun, M. A., Kaufman, J. S., Lo, B., \& Zonderman, A. B. (2012). Intimate partner violence against adult women and its association with major depressive disorder, depressive symptoms and post-partum depressions: A systematic review and meta-analysis. Social Sciences Medical, 75(6), 959-975. doi: 10.1016/j/socscimed.2012.04.025.

Brabender, V. A., Fallon, A. E., \& Smolar, A. I. (2004). Essentials of group therapy. New Jersey: John Wiley \& Sons, Inc.

Cho, S. (2008). Effects of logoautobiography program on meaning in life and mental health in the wives of alcoholics. Asian Nursing Research, 2(2), 129-139.

Cho, S., Bernstein, K. S., Roh, S., \& Chen, D. C. (2013). Logo-autobiography and its effectiveness on depressed Korean immigrant women. Journal of Transcultural Nursing, 24(1), 33-42. doi: $10.1177 / 1043659612452005$.

Crumbaugh, J. C. (1979). Logotherapy as a bridge between religion and psychotherapy. Journal of Religion and Health, 18(3), 188-191. Diunduh dari http://www.jstor.org/stable/27505512.

De Raedt. R. \& Kosten, E. H. W. (2010). Understanding vulnerability for depression from a cognitive neuroscience perspective: A reappraisal of attentional factors and a new conceptual framework. Cognitive, Affective, and Behavioral Neuroscience, 10(1), 50-70. doi: 10.3758/CABN.10.1.50.

Field, A. (2009). Discovering statistics using SPSS (3rd edition). London: SAGE Publication Ltd. 
Filson, J., Ulloa, E., Runfola, C., \& Hokoda, A. (2010). Does powerlessness explain the relationship between intimate partner violence and depression? Journal of Interpersonal Violence, 25(3), 400-415.

doi: 10.1177/0886260509334401.

Frankl, V. E. (1967). Psychotherapy and existentialism: Selected papers on logotherapy. Washington: Washington Square Press.

Frankl, V. E. (2004). Mencari makna hidup, man's search for meaning. Bandung: Yayasan Nuansa Cendekia.

Ginting, H., Naring, G., Veld, W. M. V. D., Srisayekti, W., \& Becker, E. S. (2013). Validating the Beck depression inventory - II in Indonesia's general population and coronary heart disease patients. International Journal of Clinical and Health Psychology, 13(3), 235-242. doi: 10.1016/s16972600(13)70028-0.

Goodwin, G. M. (2015). Brain imaging in understanding the action of psychotropic drugs: The drugs for depression. Annales Medico Psychologiques, 173, 259-262. doi: 10.1016/j.amp.2015.02.005.

Johnson, L. A., \& Caldwell, B. E. (2010). Race, gender, and therapist confidence: Effects on satisfaction with therapeutic relationship in MFT. American Journal of Family Therapy, 39, 307-324. doi: 10.1080/01926187.2010.532012.

Lantz, J. (1998). Viktor Frankl and interactional group therapy. Journal of Religion and Health, 37(2), 93-104. Diunduh dari http://www.jstor.org/stable/27511227.

Lianawati, E. (2009). Konflik dalam rumah tangga: Keadilan dan kepedulian proses hukum KDRT perspektif psikologi feminis. Yogyakarta: Paradigma Indonesia.
Morgan, S. (2015). Neuroscience of depression: A review. Caribbean Journal of Nursing, 2(1), 28-37.

Mustofa, A. (2011). Energi dzikir alam bawah sadar. Surabaya: Padma Press.

Nevid, J. S., Rathus, S. A., \& Greene, B. (2005). Abnormal psychology in a changing world (5th ed.). (R. Medya, W. C. Kristiaji, Penyunt., \& T. F. Indonesia, Penerj.) Jakarta: Erlangga.

Palazidou, E. (2012). The neurobiology of depression. British Medical Bulletin, 101, 127-145. doi: 10.1093/bmb/ lds004.

Schultz, D. (1991). Psikologi pertumbuhan. Yogyakarta: Kanisius.

Semiun, Y. (2006). Kesehatan mental 3. Yogyakarta: Kanisius.

Shadish, W. R., Cook, T. D., \& Campbell, D. T. (2002). Experimental and quasiexperimental designs for generalized causal inference. Boston: Houghton Mifflin Company.

Thase, M. E. (2014). Improving outcomes in depression: The role of neurobiologic processes in symptoms of depressions. The Journal of Clinical Psychiatry. Physician Postgraduate Press Inc. Diunduh dari http://www. cmeinstitute.com/Psychlopedia/Pages/ depression/12iod/sec3/section.aspx

Tomy, A. (2014). Logotherapy: A means of finding meaning to life. Journal of Psychiatric Nursing, 3(1), 1-40.

Ulrichova, M. (2015). Ethical aspect in the psychotherapy of graduates, with an accent on spirituality and religion. Procedia-Social and Behavioral Sciences, 171, 654-660. doi: 10.1016/j.sbspro.2015.01.174.

Villanueva, R. (2013). Neurobiology of major depressive disorder. Neural Plasticity, 2013, 1-7. doi: 10.1155/2013/873278.

White, J. M., David, M. K., Martin, T. F. (2015). Family theories an introduction. California: SAGE Pub Inc. 
Williamson, E. (2004). Domestic violence and health: The response of the medical profession. Bristol: The University Press.

Winters, M. R., \& Hutzell, R. R. (2010). Meaning-centered couples therapy: Logotherapy and intimate relationships. Journal Contemporary Psychotherapy, (40), 95-102. doi: 10.1007/s10879-009-9134-4.

World Health Organization (WHO). (2005). WHO multi-country study on women's health and domestic violence against women: Summary report of initial results on prevalence, health outcome and women's responses. Geneva: World Health Organization 